\title{
Toxicity of Industrial Wastewater Acting Singly or in Joint-Ratios on Clarias gariepinus
}

\author{
Aina Olubukola Adeogun and Azubuike Victor Chukwuka \\ Department of Zoology, Faculty of Science, University of Ibadan, Oyo State, Ibadan
}

\author{
Received 2012-04-23; Revised 2012-05-16; Accepted 2012-06-13
}

\begin{abstract}
Freshwater ecosystems were the most vulnerable to pollution due to their easy accessibility for disposal of wastewaters leading to deterioration of water quality. Ona river, Ibadan, Nigeria is part of a dense network of inland watercourses emptying into the Lagos lagoon and receives industrial effluents from a food and beverage industry. The single and joint-action toxicity of effluents from these industries mixed in predetermined ratios of 75:25, 50:50 and 25:75\% (v/v) (food:beverage); 100\% (food) and 100\% (beverage) respectively were tested against Clarias gariepinus fingerlings in a series of static bioassay to determine the pollution implications of interacting components of effluents and their effect on fish survival. Physicochemical parameters of exposure concentrations and effluent samples were analyzed using standard methods. Effluent samples were further analyzed for heavy metals and interactions of composite mixtures were evaluated with models such as the Synergistic Ratio (SR), concentration-addition Relative Toxic Units (RTU) and isobologram (pictorial isobole) for joint-action evaluations. The $96 \mathrm{~h} \mathrm{LC}_{50}$ values were 23.00, $31.00,71.79$ and $33.50 \%$ (food) while no $\mathrm{LC}_{50}$ value was derived for the $100 \%$ beverage effluent. Toxicity evaluation of effluent mixtures revealed decreasing toxicity in the order 75:25\% (food: beverage); 50:50\% (food: beverage); 100\% (food) and 25:75\% (food: beverage). Effluent samples and exposure concentrations were characterized by acidic pH and low DO (except for control exposures) while other effluent physicochemical analysis revealed that $\mathrm{Pb}, \mathrm{Cr}$ and $\mathrm{Fe}$ concentrations exceeded NESREA and WHO permissible limit for surface waters and protection of the aquatic ecosystem. The SR and isobologram models both depicted the food-beverage mixture of $75: 25$ and $50: 50 \%$ as synergistic and the $25: 75 \%$ mixture as antagonistic. The concentration-addition model depicted all mixture ratios as synergistic. The observed antagonistic interactions of $25: 75 \%$ (food: beverage) ratio of synchronized effluent discharge by these industries towards setting safe limits for environmental discharge could be explored.
\end{abstract}

Keywords: Antagonistic interactions, composite mixtures, toxicity, synergism, joint-action

\section{INTRODUCTION}

Industrialization is considered to be vital to a nation's socioeconomic development, however the unregulated circumstances accompanying such development especially in developing countries have led to events of surface and ground water contamination by complex interacting chemicals and substances (Alumaa et al., 2002; Clement et al., 2006; Pandey, 2006; Casarett and Klaassen, 2007 Coors and Frische, 2011; Landrum et al., 2012). This in turn has resulted in habitat loss and depletion of aquatic species diversity (MEA, 2005).

In order to have a clearer picture of interactions in natural environments, mixture toxicity protocols have been given increasing attention in the last decade as a tool for predicting impacts of chemical pollutants on aquatic organisms (Silva et al., 2002; Otitoloju, 2002; Backhaus et al., 2003; Otitoloju and Okusada, 2003; Samuel et al., 2008). This is as a result of the growing awareness that toxicity in natural ecosystems often times do not result from single substance exposure, but exposure to mixtures of toxicants (Altenburger et al., 1996; Gardner et al., 1998; Mu and LeBlanc, 2004).

Industrial effluents contain an array of components and when discharged into surface waters, give varying impacts depending on components, quantities of individual components and reaction potential in the face of other environmental factors (Adeogun and Chukwuka, 2011). 
Investigations into possible joint effects between compounds have revealed that different types of interactions do occur when mixtures of metals, for example, jointly impact aquatic organisms. A number of authors have documented reports of synergistic interactions by mixtures of metals (Otitoloju, 2002; Otitoloju and Okusada, 2003; Khangarot et al., 1982; Clark, 1992). Khangarot et al. (1982) reported that mixtures of compounds containing $\mathrm{Zn}^{2+}, \mathrm{Cu}^{2+}$ and $\mathrm{Ni}^{2+}$ mixed in the ratio of $1: 1(\mathrm{wt} / \mathrm{wt}$ ) and tested against the freshwater snail, Lymnaea acuminata had $48 \mathrm{~h} \mathrm{LC}_{50}$ values of $6.59 \mathrm{mgL}^{-1}$ for the trimetal mixture; $5.513 \mathrm{mgL}^{-1}$ for $\mathrm{Zn}$ and $\mathrm{Cu}$; and $2.68 \mathrm{mgL}^{-1}$ for $\mathrm{Cu}$ and $\mathrm{Ni}$ bimetal mixtures. The observed $\mathrm{LC}_{50}$ values were higher in toxicity levels than the computed predicted 48 $\mathrm{h} \mathrm{LC}_{50}$ values of $16.119 \mathrm{mgL}^{-1}$ for the $\mathrm{Zn}, \mathrm{Cu}, \mathrm{Ni}$ mixture; $11.789 \mathrm{mgL}^{-1}$ for $\mathrm{Zn}$ and $\mathrm{Cu}$ and $4.379 \mathrm{mgL}^{-1}$ for $\mathrm{Cu}$ and $\mathrm{Ni}$ mixture revealing that interactions between the various combinations of heavy metals in triple and binary mixtures were synergistic.

Clark (1992) recorded a growth reduction of $67.8 \%$ in Cristigera species culture when equal concentrations of $\mathrm{HgCl}_{2}, \mathrm{CuSO}_{4}$ and $\mathrm{ZnCl}_{2}$ were applied compared to $38.1 \%$ reduction when metal salts were applied individually thus suggesting a strong indication of synergistic interaction. Otitoloju (2002) observed that interactions between the test ratios of $1: 1$ and 2:3 (wt: wt) $\mathrm{Zn}-\mathrm{Cu}$ tended to conform to the model of synergism when tested against the mangrove periwinkle Tympanotonus fuscatus. Binary mixture of spent carbide and spent engine oil $(1: 1 \mathrm{wt} / \mathrm{wt})$ was also found to be more toxic than either test compound when acting singly indicating synergistic interaction (Otitoloju and Okusada, 2003). Some authors have however reported antagonistic reactions when mixtures of metals interact together. For example, Thorp and Lake (1974) observed that the $96 \mathrm{~h}$ $\mathrm{LC}_{50}$ value of a mixture of $\mathrm{Zn}$ and $\mathrm{Cd}(2: 1 \mathrm{wt} / \mathrm{wt})$ when tested against the fresh water shrimp Paratya tasmaniensis was higher $\left(2.3 \mathrm{mgL}^{-1}\right)$ and less toxic than the predicted $96 \mathrm{~h} \mathrm{LC}_{50}$ value of $1.28 \mathrm{mgl}^{-1}$ on the assumption that such interactions would be synergistic. Parrot and Sprague (1993) observed that various combinations of mixtures of $\mathrm{Cu}\left(0-150 \mathrm{mgL}^{-1}\right)$ and $\mathrm{Zn}$ $\left(0-150 \mathrm{mLL}^{-1}\right)$ acted in an antagonistic manner, producing fewer changes in DNA, RNA and protein contents of the fathead minnow Pimephales promelas than when the fishes were exposed to the individual metal constituents. Antagonistic reactions, when they occur, are considered advantageous for environmental protection as the overall effect is a reduction in the toxicity of the individual components of such mixtures to exposed organisms (Otitoloju and Okusada, 2003).
Fagade et al. (1998) reported some degree of degradation in Ogunpa and Ona rivers and concluded that increased and uncontrolled urbanization along the river course was a major contributing factor to observed poor water quality. They also noted that pollution was mostly of organic origin as a result of low industrial activities in Ibadan during the period of study. Ten species of fish belonging to seven families were found in Ona river while three species of fish belonging to two families were found in Ogunpa river. This implies greater species diversity and reduced pollution for Ona river. With the recent increase in industrial activities along Ona river, it then became necessary to evaluate the effect of mixtures of effluents from these industries on Clarias gariepinus (a commercially important fish in Nigeria whose occurrence had been recorded in this river). The fingerling stage was chosen because of its relative importance in the survival and the recruitment pattern of organisms generally. The objectives of this study were to investigate the toxicity of effluents from a food and beverage industry acting singly and in joint ratios on $C$. gariepinus and to analyze effluent quality in order to ascertain likely pollution implication on water quality and species diversity.

\section{MATERIALS AND METHODS}

\subsection{Collection of Test Organisms and Acclimation to Laboratotory Conditions}

Fingerlings of $C$. gariepinus with an average weight of $3.8 \mathrm{~g}$ were collected from a private fish farm in Ibadan, transported to the laboratory in oxygenated waterproof bags and kept in holding tanks (120L capacity) filled with dechlorinated tap water for seven days to allow them acclimatize to laboratory conditions (temperature, $\left.26.2 \pm 1.6^{\circ} \mathrm{C} ; \mathrm{pH}, 7.0 \pm 0.2 ; \mathrm{DO}, 5.6 \pm 0.3 \mathrm{mgL}^{-1}\right)$. Aeration was provided with an air pump and holding medium was changed every three days to prevent accumulation of metabolites. Fish were fed with $40 \%$ fish pellets (40\% crude protein) during the acclimatization period.

\subsection{General Bioassay Procedures 2.3. Collection of Effluents}

Whole unfiltered effluents were collected fresh from the points of discharge of the food and the beverage industries in plastic kegs and transported to the laboratory for static bioassay tests as described by Reish and Oshida (1986) and OECD (2002).

\subsection{Bioassay \\ 2.5. Single Action Toxicity Test (Food and Beverage Industry Effluent)}


Whole unfiltered effluents from a food and a beverage industry were taken as stock solutions. Required volumes were measured into graduated plastic containers and made up to the required concentration (19.1L) according to the methods of Reish and Oshida (1986) for toxicity evaluation (12g of fish:5L of water). Ten fingerlings of $C$. gariepinus $(4.6 \mathrm{~g})$ were introduced into each concentration $(10 ; 20 ; 30 ; 40 \%)$ including an untreated control $(0 \%)$ in two replicates respectively.

\subsection{Joint Action Toxicity Test (Food and Beverage Industry Effluent)}

A predetermined volume of each effluent was mixed together in the ratio $1: 1(\mathrm{v} / \mathrm{v})$ for the $50: 50 \% ; 3: 1(\mathrm{v} / \mathrm{v})$ for the $75: 25 \%$ (food: beverage) and 1:3 (v/v) for the $25: 75 \%$ (food:beverage) concentrations. These were taken as stock solutions and serial dilutions with dechlorinated tap water gave concentrations of $10,20,30,40$ and $0 \%$ (control) in two replicates. Ten fingerlings of $C$. gariepinus $(4.6 \mathrm{~g})$ were also introduced into each concentration in two replicates.

\subsection{Assessment of Quantal Response (Mortality)}

Fish were considered dead when there was a lack of both opercular and body movements when proded by a glass rod (Reish and Oshida, 1986).

\subsection{Physico-Chemical Analysis}

Physico-chemical parameters $(\mathrm{pH}$, dissolved oxygen and temperature) were measured at the beginning and end of the experiment for the test media and effluents with a digital CS-C933T Electrochemistry multimeter (Topac Instruments Inc).

Effluent samples were further analyzed for alkalinity, electrical conductivity, total solids, total suspended solids, sulphates, chlorides, phosphates and the presence of heavy metals. Alkalinity was determined by titrating a known volume of effluent sample with standardized $0.10 \mathrm{M} \mathrm{HCl}$. Sulphate $\left(\mathrm{SO}_{4}{ }^{2-}\right)$ was determined by the turbidimetric method. Chloride $\left(\mathrm{Cl}^{-}\right)$ion was analyzed by titration of a known volume of effluent with standardized $0.014 \mathrm{~N}$ mercuric (II) nitrate solution while phosphates $\left(\mathrm{PO}_{4}^{3-}\right)$ was determined colorimetrically by ascorbic acid-molybdenum blue method (APHA-AWWA, 1995).

Heavy metals were determined by digesting a known volume of effluent sample with analytical grade $\mathrm{HNO}_{3}$. The digested sample was filtered into a $20 \mathrm{~mL}$ standard flask, made up to the mark with distilled-deionized water and stored in nitric acid prewashed polyethylene bottle in the refridgerator prior to analysis. The samples were then analyzed for metals- $\mathrm{Pb}, \mathrm{Cu}, \mathrm{Cd}, \mathrm{Mn}, \mathrm{Cr}, \mathrm{Ni}, \mathrm{Ca}, \mathrm{Zn}$ and $\mathrm{Fe}$ with an Atomic Absorption Spectrophotometer (AAS).

\subsection{Statistical Analysis}

Toxicological dose response data for quantal (mortality) response were analyzed by the probit method (Finney, 1971).

To evaluate the joint toxicity of the industrial effluents, 3 models were used to quantitatively classify their mode of interaction. These were:

\subsection{Model A: Synergistic Ratios (SRs)}

Joint action toxicity data were analyzed based on the synergistic ratio model after Hewlett and Plackett (1969) where:

$$
\mathrm{S} . \mathrm{R} \text { index }=\frac{\mathrm{LC}_{50} \text { of chemical acting alone }}{\mathrm{LC}_{50}}
$$

And $S . R=1$ : joint action is additive, $S . R<1$ : joint action is antagonistic $S . R>1$ : joint action is synergistic

\subsection{Model B: Concentration-Addition Model}

This model proposed by Anderson and Weber (1975) assumes that similarly acting toxicants mixed in any proportion, will add together to give the observed response. In evaluating the joint action, a predicted response value (e.g., $\mathrm{LC}_{50}$ ) is derived by summing up the $\mathrm{LC}_{50}$ values of the separate toxicants according to the proportion of their contribution in the mixture. The predicted $\mathrm{LC}_{50}$ values are compared to the observed $\mathrm{LC}_{50}$ value of the mixture to give the Relative Toxicity Unit (RTU) which will be used to classify the type of interaction between the effluent mixtures as follows:

- Additive if the observed $\mathrm{LC}_{50}$ value of the mixture is equal to the predicted $\mathrm{LC}_{50}$ value

- Synergistic if the observed $\mathrm{LC}_{50}$ value of the mixture is less than the predicted $\mathrm{LC}_{50}$ value

- Antagonistic if the observed $\mathrm{LC}_{50}$ value of the mixture is greater than the predicted $\mathrm{LC}_{50}$ value

The relationship of the derived $\mathrm{LC}_{50}$ values to the predicted $\mathrm{LC}_{50}$ values (RTU) is estimated as:

$\mathrm{RTU}=\underline{\text { Predicted }} \mathrm{LC}_{50}$ value

Experimentally derived $\mathrm{LC}_{50}$ value

And $\mathrm{RTU}=1$ describes an additive action, $\mathrm{RTU}<1$ describes antagonism and RTU $>1$ describes synergism. 


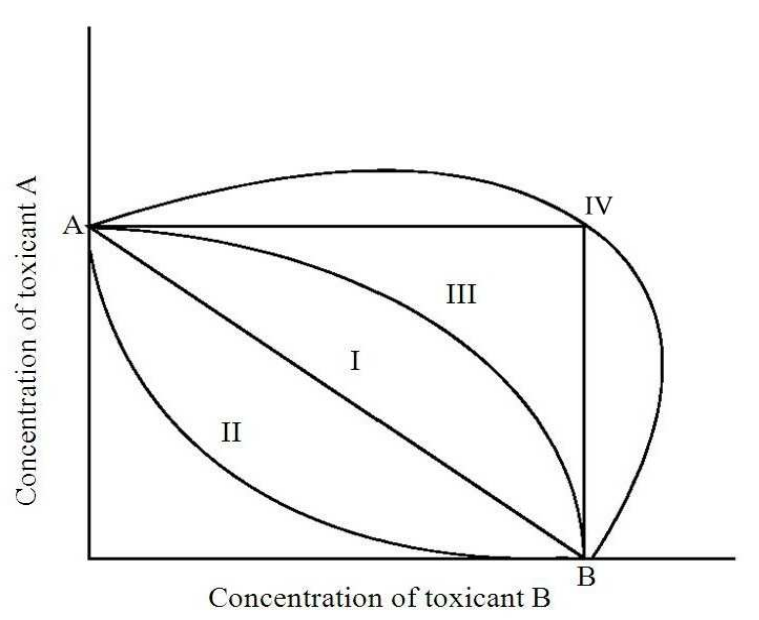

Fig. 1. Isoboles depicting the types of interactions between two chemicals A and B (Ariens et al, 1976). Isobole I depicts additive action; Isobole II depicts synergism; Isobole III depicts subadditive action; Isobole IV depicts antagonism.

\subsection{Model C: Isobologram Model}

Isobolograms (Ariens et al., 1976) as depicted in Fig. 1 involves the representation of the joint-actions between binary mixtures of test chemicals. Each isobole (I-IV) represents the amount of the toxicants in the formulations which produces a biological response. In the theoretical isobole (Fig. 1) points A and B represent the amounts of toxicant $\mathrm{A}$ and $\mathrm{B}$ which individually (singly) produced the biological response $\left(\mathrm{LC}_{50}\right.$ in this study) which when connected gives the additive line. Isoboles (I-IV) represent the interactions of the test mixtures as described in the legend to Fig. 1. Three combinations of binary mixtures of effluents were tested at different ratios and individual effluents were also tested. The data accruing from the derived $96 \mathrm{hr} \mathrm{LC}_{50}$ values were fitted into isobolograms and compared to the theoretical model (Fig. 1) to extrapolate the type of jointaction interactions in this study (Ariens et al., 1976).

\section{RESULTS}

\subsection{Physicochemical Properties}

Table 1a and $\mathbf{b}$ show the mean variation in some physico-chemical parameters of exposure concentrations and effluents from the food and beverage industries. Average temperature for exposure concentrations were not significantly different $\left(27.0-28.2^{\circ} \mathrm{C}\right)$ and were within the range reported for tropical environment. Acidic $\mathrm{pH}$ (5.50-6.98) and low DO (0.4-3.6 $\left.\mathrm{mg} \mathrm{L}^{-1}\right)$ values were however recorded in exposure concentrations except the untreated control (Table 1a). The mean variation in physico-chemical parameters was also higher in food and beverage effluent (food was higher in values than beverage) than in the dilution water (Table 1b). Evident from the data obtained was that both wastes were acidic in nature, had very low DO and contained $\mathrm{Fe}, \mathrm{Cr}$ and $\mathrm{Pb}$ in amounts that exceeded the permissible limits prescribed by NESREA \{National Environmental Standards and Regulations and Enforcement Agency\}, (NESREA, 2009) Nigeria for food and beverage industry effluents discharged into surface waters and WHO \{World Health Organization $\}$ (WHO, 2004) guideline levels for drinking water and protection of aquatic ecosystems.

\subsection{Relative Toxicity of Single and Joint Effluent Exposures on $C$. gariepinus \\ 3.2. Single Action Toxicity (Food and Beverage Industry Effluent)}

The analysis of the toxicity regime response data for food industry effluent on C. gariepinus, revealed a derived lethal concentration ranging from $34.00 \%\left(96 \mathrm{~h} \mathrm{LC}_{50}\right)$ to $50.00 \%$ (48 $\mathrm{h} \mathrm{LC}_{50}$ ) (Table 2). The $\mathrm{LC}_{50}$ at $24 \mathrm{~h}$ was not detectable by the probit analysis giving values $>100 \%$. The $96 \mathrm{~h} \mathrm{LC}_{50}$ values of the beverage industry effluent could not be determined as only $15.00 \%$ mortality was recorded in the highest concentration of $40.00 \%$ at the end of the exposure period compared with $70.00 \%$ mortality recorded in the food industry effluent using the same concentration range. This implies that the food industry effluent was more toxic than the beverage industry effluent:

\subsection{Joint Action Toxicity (Food and Beverage Industry Effluents)}

Results of the dose response data of $C$. gariepinus exposed to binary mixtures of food and beverage industry effluent in the ratios $3: 1(\mathrm{v} / \mathrm{v} ; 75: 25 \%)$ showed a derived toxicity index ranging from $23.27 \%\left(96 \mathrm{hr} \mathrm{LC}_{50}\right)$ to $30.77 \%$ (24 $\mathrm{h} \mathrm{LC}_{50}$ values) (Table 2). Unlike the single toxicity of food industry effluent, binary mixtures gave Toxicity Factors (TF) with close and nearly overlapping ranges i.e., 1.00-1.30 between 24 and $96 \mathrm{~h} \mathrm{LC}_{50}$ data. These results also depict that the addition of beverage industry effluent to food industry effluent in the ratio specified potentiated the ability of the food industry effluent to cause lethal effects to the fish in smaller amounts and within $24 \mathrm{~h}$ of exposure.

Analysis of exposure induced mortality of binary mixtures of food and beverage industry effluent in the 
ratio $1: 1(\mathrm{v} / \mathrm{v} ; 50: 50 \%)$ showed that an increase in the ratio of beverage industry effluent to food industry effluent increased the amount of effluent required to cause detectable toxicity to $50 \%$ of the exposed Clarias population within $24 \mathrm{~h}$ (Table 2). The increased toxicity of combinations of these effluents was apparent in lower $\mathrm{LC}_{50}$ values derived (Table 2), where a smaller amount of the 75:25\% (food: beverage) resulted in 50\% mortality in exposed fish compared to the other mixture ratios and single acting effluent.

Based on the $96 \mathrm{~h} \mathrm{LC}_{50}$ values of the effluent mixtures and single exposures, the relative toxicity analyses showed that the 75:25\% (food:beverage) mixture was about 1.4 and the 50:50\% (food:beverage) were 1.3 times more toxic than the food industry effluent used singly. The single acting food industry effluent was more toxic than the $25: 75 \%$ (food:beverage) mixture by a factor of 2 (Fig. 2).

The synergistic evaluation of the food-beverage industry effluent mixtures on C. gariepinus based on the Synergistic Ratio (SR) model revealed that the interactions between the food-beverage effluent ratios of 75:25 and $50: 50 \%$ conformed with the model of synergism i.e., S.R. $>1$ except for the $25: 75 \%$ mixture which aligned with the antagonistic model $(\mathrm{SR}=0.47)$ (Table 3).

Table 1a. Some physico chemical parameters of exposure concentrations

\begin{tabular}{|c|c|c|c|c|c|c|}
\hline Parameter & $\begin{array}{l}\text { Exposure } \\
\text { concentrations (\%) }\end{array}$ & $\begin{array}{l}\text { Food } \\
(100 \%)\end{array}$ & $\begin{array}{l}\text { Beverage } \\
(100 \%)\end{array}$ & $\begin{array}{l}\text { Food:Beverage } \\
(50: 50 \%)\end{array}$ & $\begin{array}{l}\text { Food:Beverage } \\
(75: 25 \%)\end{array}$ & $\begin{array}{l}\text { Food:Beverage } \\
(25: 75 \%)\end{array}$ \\
\hline Temperature & 0.00 & 27.80 & 27.80 & 27.80 & 27.80 & 27.80 \\
\hline \multirow[t]{4}{*}{$\left({ }^{\circ} \mathrm{C}\right)$} & 10.00 & 27.70 & 27.20 & 27.90 & 27.80 & 27.90 \\
\hline & 20.00 & 27.90 & 27.00 & 27.80 & 28.00 & 27.20 \\
\hline & 30.00 & 28.00 & 27.30 & 28.00 & 27.90 & 27.70 \\
\hline & 40.00 & 28.20 & 27.70 & 28.20 & 28.20 & 27.40 \\
\hline \multirow[t]{5}{*}{$\mathrm{pH}$} & 0.00 & 7.02 & 7.02 & 7.02 & 7.02 & 7.02 \\
\hline & 10.00 & 6.77 & 6.98 & 6.06 & 5.91 & 6.95 \\
\hline & 20.00 & 6.58 & 6.95 & 5.91 & 5.68 & 6.85 \\
\hline & 30.00 & 5.95 & 6.89 & 5.81 & 5.50 & 6.74 \\
\hline & 40.00 & 5.68 & 6.79 & 5.67 & 5.48 & 6.61 \\
\hline \multirow{5}{*}{$\begin{array}{l}\text { Dissolved oxygen } \\
\left(\mathrm{mgL}^{-1}\right)\end{array}$} & 0.00 & 5.60 & 5.60 & 5.60 & 5.60 & 5.60 \\
\hline & 10.00 & 2.80 & 3.60 & 2.40 & 2.20 & 3.20 \\
\hline & 20.00 & 2.40 & 3.30 & 2.20 & 1.80 & 2.80 \\
\hline & 30.00 & 1.80 & 3.20 & 0.80 & 0.80 & 2.40 \\
\hline & 40.00 & 1.20 & 3.00 & 0.60 & 0.40 & 2.20 \\
\hline
\end{tabular}

Table 1b. Physico-chemical parameters of Dilution water, Industrial effluent and NESREA/ WHO's standard for industrial effluent

\begin{tabular}{|c|c|c|c|c|c|}
\hline Parameter & $\begin{array}{l}\text { Dilution } \\
\text { water }\end{array}$ & Food & Beverage & $\begin{array}{l}\text { NESREA } \\
-2009\end{array}$ & $\begin{array}{l}\text { WHO } \\
-2011 \\
\end{array}$ \\
\hline$\overline{\mathrm{pH}}$ & 7.02 & 5.46 & 5.59 & $6.50-8.50$ & $6.50-8.00$ \\
\hline $\mathrm{DO}(\mathrm{mg} / \mathrm{L})$ & 5.60 & 0.10 & 0.20 & 6 & 4 \\
\hline $\mathrm{EC}$ & 119 & 1380 & 880 & - & 500 \\
\hline $\mathrm{TS}(\mathrm{mg} / \mathrm{L})$ & 4.26 & 1600 & 670 & 2000 & 2000 \\
\hline TSS (mg/L) & - & 130 & 38 & 0.25 & - \\
\hline Alkalinity (mg/L) & 9.00 & 580 & 220 & 150 & - \\
\hline $\mathrm{Cl}^{-}$ & 2.61 & 310 & 225 & 300 & $200-300$ \\
\hline $\mathrm{PO}_{4}{ }^{3-}$ & - & 3.49 & 2.80 & 3.50 & 5 \\
\hline $\mathrm{SO}_{4}{ }^{2-}$ & - & 43.4 & 38.4 & 250 & 250 \\
\hline $\mathrm{NO}_{3}{ }^{2-}$ & - & 9.82 & 1.55 & 10 & 10 \\
\hline $\mathrm{Pb}(\mathrm{mg} / \mathrm{L})$ & - & 0.32 & 0.13 & 0.05 & 0.01 \\
\hline $\mathrm{Cu}(\mathrm{mg} / \mathrm{L})$ & - & 0.02 & 0.03 & 1 & 2 \\
\hline $\mathrm{Cd}(\mathrm{mg} / \mathrm{L})$ & - & 0.01 & 0.01 & 1 & 0.003 \\
\hline $\mathrm{Ni}(\mathrm{mg} / \mathrm{L})$ & - & - & - & 0.05 & 0.07 \\
\hline $\mathrm{Cr}(\mathrm{mg} / \mathrm{L})$ & - & 0.06 & 0.02 & 0.01 & 0.01 \\
\hline $\mathrm{Mn}(\mathrm{mg} / \mathrm{L})$ & - & 0.54 & 0.06 & 0.20 & - \\
\hline $\mathrm{Zn}(\mathrm{mg} / \mathrm{L})$ & - & 1.77 & 0.33 & 2 & $3.00-5.00$ \\
\hline $\mathrm{Fe}(\mathrm{mg} / \mathrm{L})$ & - & 4.13 & 2.50 & 0.10 & 0.30 \\
\hline
\end{tabular}

NESREA- National Environmental Standards Regulation and Enforcement Agency WHO-World Health Organisation 
Table 2. Relative toxicities of single and binary effluent mixtures of food and beverage industries on C. gariepinus

\begin{tabular}{llllllll}
\hline Effluent type and ratio & Time $(\mathrm{h})$ & $\mathrm{LC}_{90}$ & $\mathrm{LC}_{50}$ & $\mathrm{LC}_{10}$ & $\mathrm{Df}$ & $\mathrm{TF}$ & Probit line Equation \\
\hline \multirow{2}{*}{ Food (100\%) } & 24 & $\mathrm{ND}$ & $\mathrm{ND}$ & 83.33 & 3 & $\mathrm{ND}$ & $\mathrm{Y}=0.15 \times-2.50$ \\
& 48 & 79 & 50 & 20.37 & 3 & 1.47 & $\mathrm{Y}=1.35 \times-17.50$ \\
& 72 & 60.29 & 42.65 & 19.12 & 3 & 1.25 & $\mathrm{Y}=1.7 \times-22.50$ \\
& 96 & 50.00 & 34.00 & 16.96 & 3 & 1 & $\mathrm{Y}=2.35 \times-30.00$ \\
Food: Beverage & 24 & 43.08 & 30.77 & 18.46 & 3 & 1.3 & $\mathrm{Y}=3.25 \times-50.00$ \\
(75\%:25\%) & 48 & 41.05 & 29.11 & 17.16 & 3 & 1.25 & $\mathrm{Y}=3.35 \times-47.50$ \\
& 72 & 40.44 & 28.68 & 16.91 & 3 & 1.23 & $\mathrm{Y}=3.40 \times-47.50$ \\
& 96 & 34.24 & 23.27 & 12.31 & 3 & 1 & $\mathrm{Y}=3.65 \times-35.00$ \\
Food: Beverage (50\%:50\%) & 24 & $\mathrm{ND}$ & $\mathrm{ND}$ & 50 & 3 & $\mathrm{ND}$ & $\mathrm{Y}=0.30 \times-5.00$ \\
& 48 & 62.86 & 40 & 17.14 & 3 & 1.32 & $\mathrm{Y}=1.75 \times-20.00$ \\
& 72 & 53.49 & 34.88 & 16.28 & 3 & 1.15 & $\mathrm{Y}=2.15 \times-25.00$ \\
Food: Beverage (25\%:75\%) & 24 & 52.22 & 30.27 & 16.88 & 3 & 1 & $\mathrm{Y}=2.8 \times-32.50$ \\
& 72 & $\mathrm{ND}$ & $\mathrm{ND}$ & $\mathrm{ND}$ & - & - & - \\
& 72 & $\mathrm{ND}$ & $\mathrm{ND}$ & $\mathrm{ND}$ & - & - & - \\
\end{tabular}

$\mathrm{Df}=$ degree of freedom; $\mathrm{ND}=$ not determinable; $\mathrm{TF}=$ Toxicity factor $=24 \mathrm{hr}, 48 \mathrm{hr}, 72 \mathrm{hr} \mathrm{LC}_{50}$ values $/ 96 \mathrm{hr} \mathrm{LC}_{50}$ values

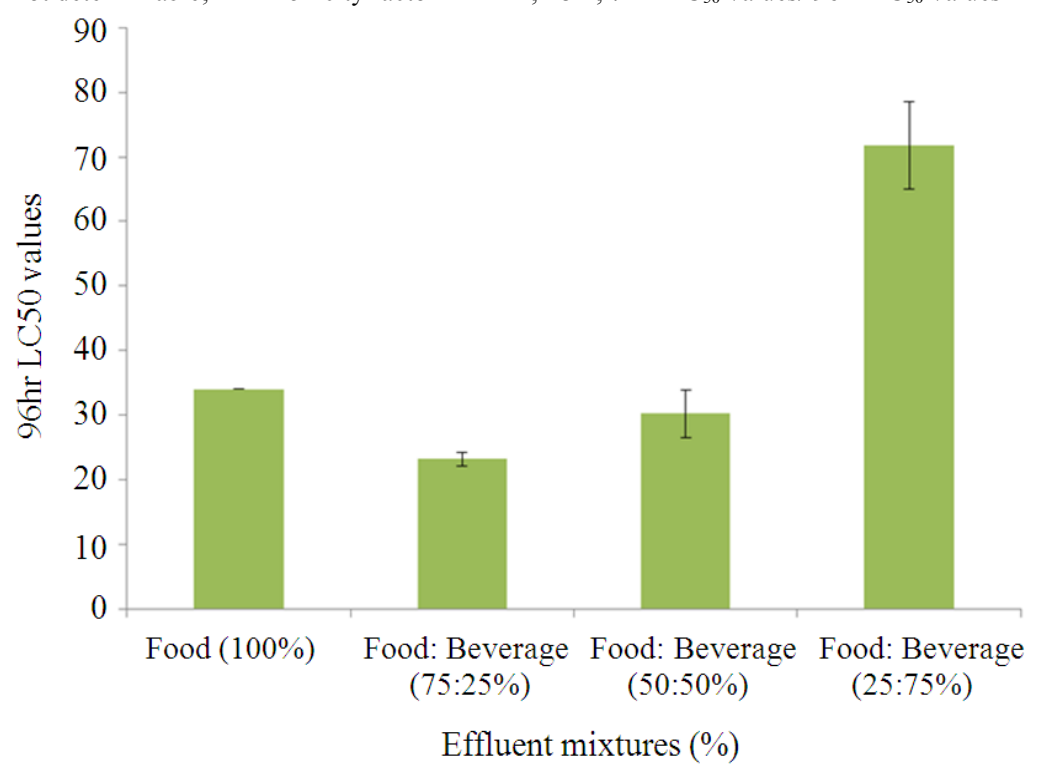

Fig. 2. Relative toxicity of food industry effluent, beverage industry effluent and their mixtures based on $96 \mathrm{hr} \mathrm{LC}_{50}$ values

The synergistic ratios derived from the $50: 50 \%$ mixtures (1.08) were lower than that for $75: 25 \%$ ratio (1.46) indicating lower potency (Table 3).

Analysis of the concentration mortality data using the concentration-addition model showed that the interactions between the food industry effluent and beverage industry effluent for all ratios were in conformity with the model of synergism (RTU $>1$ ) (Table 4). For the purpose of using the concentration-addition model, a $96 \mathrm{~h} \mathrm{LC}_{50}$ of $100 \%$ was assumed. This was as a result of the low toxicity of the beverage industry effluent and the consequent inability to derive the $96 \mathrm{~h} \mathrm{LC}_{50}$.
A further subjection of the joint-action toxicity data by fitting the derived $96 \mathrm{~h} \mathrm{LC}_{50}$ values of the tested mixtures and single compounds into the isobologram and comparing it to the theoretical pictorial isobole (Fig. 1) revealed that the resultant isobole from the binary mixtures of the effluents confirmed the results of the SR model which showed that the food-beverage ratio of $75: 25 \%$ was synergistic. Howevers contrary to the SR and RTU models, the isobologram model depicted that the food-beverage ratio $50: 50 \%$ conformed to the criteria for sub-additive interaction while the food-beverage ratio $25: 75 \%$ conformed to the criteria for antagonistic interaction (Fig. 3). This suggests that an increase in the concentration of the beverage effluent resulted in lower toxicity of the mixtures. 


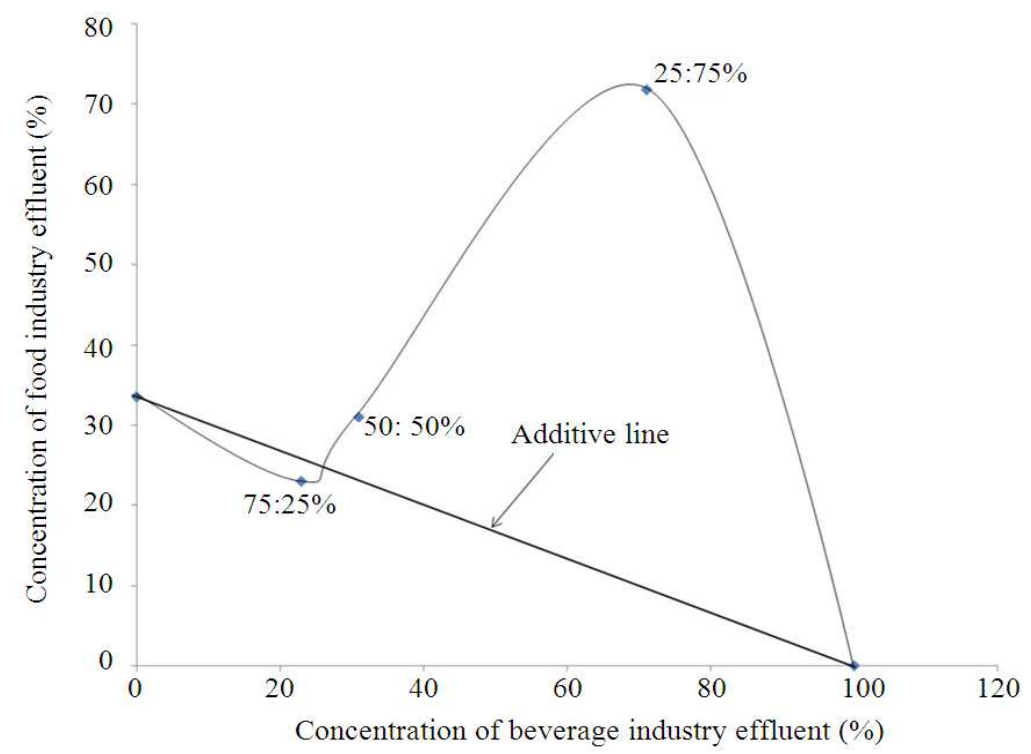

Fig. 3. Isobole representation of the joint-action of the food-beverage industry effluent when tested against C.gariepinus

Table 3. Summary of relative toxicity and synergistic ratios of binary mixtures of food and beverage industry effluent on C. gariepinus after $96 \mathrm{~h}$

\begin{tabular}{|c|c|c|c|c|c|c|}
\hline Effluent ratios (v/v) & $\begin{array}{l}\mathrm{LC}_{90} \\
(95 \% \text { C.L })\end{array}$ & $\begin{array}{l}\mathrm{LC}_{50}(95 \% \text { C.L }) \\
(\%)\end{array}$ & $\begin{array}{l}\mathrm{LC}_{10}(95 \% \text { C.L }) \\
(\%)\end{array}$ & $\begin{array}{l}\mathrm{df} \\
(\%)\end{array}$ & $\begin{array}{l}\text { Probit line } \\
\text { equation }\end{array}$ & $\begin{array}{l}\text { Synergistic } \\
\text { ratio }\end{array}$ \\
\hline Food-100\% & $50.00(50.00-52.27)$ & $34.07(34.04-34.09)$ & $16.96(15.91-18.00)$ & 3 & $\mathrm{Y}=2.35 \mathrm{x}-30$ & - \\
\hline Food/Beverage $(75: 25 \%)$ & $34.24(33.33-35.14)$ & $23.27(22.22-24.32)$ & $12.31(11.11-13.51)$ & 3 & $Y=3.65 x-35$ & 1.46 \\
\hline Food/Beverage $(50: 50 \%)$ & $52.22(52.17-52.27)$ & $30.27(26.56-34.78)$ & $16.88(13.64-20.12)$ & 3 & $Y=2.8 x-32.5$ & 1.08 \\
\hline Food/Beverage $(25: 75 \%)$ & $95.11(88.15-100.0)$ & $71.79(65.0-78.75)$ & $23.53(21.4-25.0)$ & 3 & $Y=0.85 x-10$ & 0.47 \\
\hline Beverage $(100 \%)$ & ND & ND & ND & - & - & - \\
\hline
\end{tabular}

Where $\mathrm{ND}=$ Not Determinable

Table 4: Synergistic analysis of effluent binary mixtures (based on concentration-addition model) tested against C. gariepinus

\begin{tabular}{|c|c|c|c|}
\hline $\begin{array}{l}\text { Test compound } \\
\text { Mixtures }\end{array}$ & $\begin{array}{l}\text { Experimentally observed } \\
96 \mathrm{hLC}_{50}(95 \% \mathrm{CL})(\%)\end{array}$ & $\begin{array}{l}\text { Predicted 96h } \\
\text { LC }_{50}(95 \% \mathrm{CL})(\%)\end{array}$ & RTU \\
\hline $\begin{array}{l}\text { Food:Beverage } \\
(75: 25 \%)\end{array}$ & 23.00 & 42.25 & 1.83 \\
\hline $\begin{array}{l}\text { Food:Beverage } \\
(50: 50 \%)\end{array}$ & 31.00 & 66.75 & 2.15 \\
\hline Food: Beverage & 71.79 & 83.38 & 1.16 \\
\hline
\end{tabular}

$(25: 75 \%)$

RTU= Relative Toxicity Unit

\section{DISCUSSION}

Acidic $\mathrm{pH}$ of the effluents used in this study resulted in lowering of the $\mathrm{pH}$ of exposure concentrations and this acidity could be attributed to mineral acids such as nitric, phosphoric and sulphuric acids which are essential raw materials for most industries. Low values of $\mathrm{pH}$ in exposure concentrations are a significant indication of the likely effects of effluents on the water quality of the receiving river as acidic $\mathrm{pH}$ affects metal solubility, alkalinity and water hardness. Low $\mathrm{pH}$ also has a negative effect on the metabolic activities of aquatic organisms (Wang et al., 2002) and values reported were appreciably lower than
NESREA (2009) and WHO (2004) permissible limit for surface water quality.

The low levels of dissolved oxygen in the effluents and exposure concentrations (except control) was due to the high levels of nutrients, organic load and total solids content of the effluent and was lower than the NESREA (2009) and WHO (2004) guideline levels for surface waters and protection of aquatic ecosystem. DO is very crucial for the survival of aquatic organisms and the low levels recorded in exposure concentrations in spite of artificial respiration could be as a result of the high amount of oxygen required for chemical oxidation and decomposition of nutrients thereby depleting available 
oxygen required for respiration of fish leading to asphyxiation in higher concentrations and more toxic mixtures. This observation is in agreement with the study of Fakayode (2005) who observed that industrial effluents discharged into Alaro river resulted in a depletion of DO downstream from the point of effluent discharge and could have dire consequences for aquatic organisms.

Effluents had a high EC, TS, TSS, Alkalinity, $\mathrm{Cl}^{-}$, $\mathrm{PO}_{4}{ }^{3-}$ and $\mathrm{SO}_{4}{ }^{2-}$ compared with dilution water. The food industry effluent also had higher values indicating the presence of more toxic components than the beverage industry effluent. The activities of industries that require the use of phosphoric acid, hydrochloric acid, common salt $(\mathrm{NaCl})$, sulphate salts and chloride containing compounds as raw materials paritcularly in the food and beverage industries and detergents for washing purposes in most industries (Fakayode, 2005) could be responsible for the high levels of the values recorded from effluent subsamples.

The levels of lead, iron and chromium recorded in effluent samples exceeded NESREA (2009) and WHO (2004) limit for food and beverage industry effluents discharged into surface waters. Some degree of accumulation is anticipated in the receiving Ona river. The anthropogenic contribution to the levels of metals in water, soil and food is well recognized (Backhaus et al., 2003) and on a broad perspective, the implications of these findings on freshwater habitats are not likely to be favorable. Reports have it that freshwater organisms and their habitats have evolved with low metal levels thus small amount of metal pollutants introduced into their environment can augment existing concentrations resulting in adverse effects (Hill, 2010). The high concentration of iron $(\mathrm{Fe})$ in effluent sample resulted in a corresponding decrease in dissolved oxygen concentrations in effluent sample and exposure concentrations. This observation is consistent with WHO (2004) report that depletion of DO in water supply increases the concentration of ferrous ion in solution.

These findings are particularly significant because preliminary evaluation of the fish and fisheries of Ona river revealed that only two species belonging to two families were occasionally encountered upstream from the point of effluent discharge and fish were no longer caught up to $2500 \mathrm{~m}$ downstream. The few species presently observed in catches compared with 10 species reported by Fagade et al. (1998) is a clear indication of the negative impact of pollutants on species diversity in river Ona. This coupled with the fact that some individuals resident around the industrial estate and downstream of the receiving river use its water for drinking and other domestic purposes with little or no pretreatment under acute or chronic water shortage should be of serious health concern. Risks associated to humans on exposure of hexavalent chromium compounds through drinking water include enhanced UV- induced skin cancer (Costa and Klein, 2006) and stomach cancer (Sedman et al., 2006). Lead-induced gametotoxic effects have been demonstrated in both male and female animals (Goyer, 1996). There is also evidence that lead may disrupt the hypothalamic-pituitary-gonadal axis. An increase in Maternal Blood Lead Levels (MBLL) may also contribute to premature birth and reduced birth weight in humans (ATSDR, 2005).

According to (Stenersen, 2004), if a non-toxic single acting substance enhances the toxicity of another, it is a synergistic interaction. If it reduces the toxicity of another it is an antagonistic interaction. A comparative evaluation of the single and joint toxicity of the food and beverage industry effluents revealed that most of the predetermined effluent ratios used in this study showed synergistic interactions as depicted by the Toxicity Factors (TF) and the synergistic evaluation models. In other words the addition of the beverage industry effluent potentiated the food industry effluent, but at increased ratios there was a deviation from potentiation towards sub-additive and antagonistic interactions. This trend is in line with the report of Otitoloju (2005) that the types of interactions exhibited by components of mixtures are largely dependent on the proportion of their occurrence in the mixture. Chukwu and Lawson (2009) also reported the possibility of synergistic reactions occurring when mixtures containing heavy metals interact with other pollutant mixtures present in the ecosystem.

From synergistic model analyses, the Synergistic Ratio (SR) model and isobologram model, showed complementary results, both indicating that the foodbeverage ratio of $75: 25$ and $25: 75 \%$ were synergistic and antagonistic respectively. The concentration-addition model classified all the effluent interactions as synergistic. This confirms reports (Chukwu and Lawson, 2009; Chapman, 2000) on the relative advantage of the SR model over other models in classifying joint-action binary and multiple mixtures and contrary to Samuel et al. (2008) each model may not be independently reliable for all varieties of mixtures. Furthermore it may be inferred that joint-action tests involving mixtures with components having far-apart toxicities and interactions bordering on synergistic (according to the SR model) and sub-additive (according to the isobologram model) may require the complementary role of the isobologram for accurate classification. 


\section{CONCLUSION}

The higher mortalities recorded in composite mixtures compared with single concentrations imply that most of the mixture ratios were more toxic than each of the effluents acting singly thus indicating synergistic interaction. The deviation of effluent mixtures from potentiation to antagonism at certain ratios may be a promising tool for effluent discharge control. Industrial effluents of adjacent or proximal industries are most often discharged into common channels that end up as a point discharge into nearby water bodies, thus effluent discharge volumes could be adjusted and synchronized to ratios that can undoubtedly minimize toxicity. Furthermore, since the effluent discharge is not totally avoidable, poor water quality, fish mortality and the consequent reduction in species diversity due to industrial activities could be avoided if such management approach is considered. This, however, do not dispute the fact that the institutionalization and enforcement of stringent measures (i.e., policies and laws) to ensure compliance will go a long way to improve the quality of surface waters of the Nigerian environment.

The complementary role of the synergistic evaluation models should be further explored, so that predictive measures borne out of joint-action toxicity testing are developed with a high level of accuracy, especially for the purpose of establishing environmental safe limits for effluent discharges.

\section{REFERENCES}

Adeogun, A.O. and A.V. Chukwuka, 2011. Effect of textile factory effluent on otolith and somatic growth parameters in Clarias gariepinus. Zoologist, 9: 70-77.

ATSDR, 2005. Toxicological profile for arsenic (update), draft for public comment. Department of Health and Human Services.

Altenburger, R., W. Boedeker, M. Faust and L.H. Grimme, 1996. Regulations for combined effects of pollutants: Consequences from risk assessment in aquatic toxicology. Food Chem. Toxicol., 34: 11551157. PMID: 9119330

Alumaa, P., U. Kirso, V. Petersell and E. Steinnes, 2002. Sorption of toxic heavy metals to soil. Int. J. Hyg. Environ. Health, 204: 375-376. PMID: 11885365

Anderson, P.D. and L.J. Weber, 1975. The toxicity to aquatic population of mixtures containing certain heavy metals. Proceedings of the International Conference on Heavy Metal in the Environment, (HME' 75), Institute Environ. Study University, Toronto, pp: 933-953.
APHA-AWWA, 1995. Standard Methods for the Examination of Water and Wastewater. 18th Edn., Joint Publication of American Public Health Association, Washington D.C.

Ariens, E.J., A.M. Simmons and J. Offermeier, 1976. Interactions Between Substances in Toxicology. 1st Edn., Academic Press, New York, ISBN-10: 012060552X pp: 252.

Backhaus, T., R. Altenburger, A. Arrhenius, H. Blanck and M. Faust et al., 2003. The BEAM-project: Prediction and assessment of mixture toxicities in the aquatic environment. Cont. Shelf Res., 23: 17571769. DOI: 10.1016/j.csr.2003.06.002

Chapman, P.M., 2000. Whole effluent toxicity testingusefulness, level of protection and risk assessment. Environ. Toxicol. Chem., 19: 3-13. DOI: 10.1002/etc.5620190102

Chukwu, L.O. and O.F. Lawson, 2009. Physiological stress response of Macrobrachium vollehoevenii (Herklots 1857) to interacting effects of binary mixtures of industrial effluents. African J. Biotechnol., 8: 1713-1719.

Clark, R.B., 1992. Marine Pollution. 3rd Edn., Oxford University Press., Oxford, pp: 169.

Clement, L., O. Thas, P.A. Vanrolleghem and J.P. Ottoy, 2006. Spatio-temporal statistical models for river monitoring networks. Water Sci. Technol., 53: 9-15. PMID: 16532730

Coors, A. and T. Frische, 2011. Predicting the aquatic toxicity of commercial pesticide mixtures. Environ. Sci. Europe., 23:22-22. DOI: 10.1186/2190-4715-23-22

Costa, M. and C.B. Klein, 2006. Toxicity and carcinogenicity of chromium compounds in humans. Crit. Rev. Toxico., 36: 155-163. PMID: 16736941

Fagade, S.O., A.A. Adebisi, R.J. Kolo, B.F. Elemi and A.A. Adeosun et al., 1998. Urbanization and degradation of Aquatic Resources: The Ibadan Experience. Proceedings of the 14th Annual Conference of Fisheries Society of Nigeria, (FSN' 98), Jan. 19-23, Ibadan, Nigeria. pp: 18-18.

Fakayode, S.O., 2005. Impact assessment of industrial effluent on water quality of the receiving Alaro River in Ibadan, Nigeria. AJEAM-RAGEE 10: 1-13.

Finney, D.J., 1971. Probit Analysis. 3rd Edn., Cambridge University Press, London, pp: 333.

Gardner, H.S., L.M. Brennan, M.W. Toussaint, A.B. Rosencrance and E.M. Boncavage-Hennessey et al., 1998. Environmental complex mixture toxicity assessment. Environ. Health. Persp., 106: 12991305. PMID: 9860885 
Goyer, R.A., 1996. Cassarett and Doull's Toxicology: The Basic Science of Poisons. 5th Edn., McGrawHill, New York.

Hewlett, P.S. and R.L. Plackett, 1969. A unified theory for quantal responses to mixtures of drugs: Noninteractive action. Biometrics, 15: 591-610.

Hill, M.K., 2010. Understanding Environmental Pollution: A Primer. 3rd Edn., Cambridge University Press, Cambridge, ISBN-10: 0521736692 pp: 602.

Khangarot, B.S., S. Mathur and V.S. Durve, 1982. Comparative toxicity of heavy metals and interaction of metals on a freshwater pulmonate snail lymnaea acuminata (Lamarck). Acta Hydrochim. Hydrobiol. 10: 367-375. DOI: 10.1002/aheh.19820100410

Landrum, P.F., P.M. Chapman, J. Neff and D.S. Page, 2012. Evaluating the aquatic toxicity of complex organic chemical mixtures: Lessons learned from polycyclic aromatic hydrocarbon and petroleum hydrocarbon case studies. Integr. Environ. Assess Manag., 8: 217-230. DOI: 10.1002/ieam.277

Casarett, L.J. and C.D. Klaassen, 2007. Casarett and Doull's Toxicology: The Basic Science of Poisons. 7th Edn., McGraw-Hill, New York, ISBN-10: 9780071470513 pp: 1310.

MEA, 2005. Ecosystems and Human Well-Being: Current State and Trends. 1st Edn., Island Press, Washington, ISBN-10: 1559632275 pp: 917.

$\mathrm{Mu}, \mathrm{X}$. and G.A. LeBlanc, 2004. Synergistic interaction of endocrine-disrupting chemicals: Model development using an ecdysone receptor antagonist and a hormone synthesis inhibitor. Environ. Toxicol. Chem., 23: 1085-1091. DOI: 10.1897/03-273

NESREA, 2009. National Environmental (Food, Beverage and Tobacco Sector) Regulations. Federal Republic Nigeria Official Gazette, 65: 96-123.

OECD, 2002. Guidelines for Testing of Chemicals. 1st Edn., OECD Publishing, ISBN-10: 926416054X, pp: 212.

Otitoloju, A.A., 2002. Evaluation of the joint-action toxicity of binary mixtures of heavy metals against the mangrove periwinkle Tympanotonus fuscatus var radula (L.). Ecotoxicol. Environ. Saf. 53: 404415. PMID: 12485585

Otitoloju, A.A. and O.B. Okusada, 2003. Impact of spent engine oil and carbide acting singly and jointly against gutter dwelling guppy, Poecilica reticulata. Zoologist, 2: 46-54.
Otitoloju, A.A., 2005. Crude oil plus dispersant: Always a boon or bane? Ecotoxicol. Environ. Safety, 60: 198-202. PMID: 15546636

Pandey, S.N., 2006. Accumulation of heavy metals (Cd, $\mathrm{Cr}, \mathrm{Cu}, \mathrm{Ni}$ and $\mathrm{Zn}$ ) in Raphanus sativus $\mathrm{L}$. and Spinacia oleracea L. plants irrigated with industrial effluent. J. Environ. Biol., 27: 381-384. PMID: 17436528

Parrot, J.L. and J.B. Sprague, 1993. Patterns in toxicity of sublethal mixtures of metals and organic chemicals determined by Microtox ${ }^{\circledR}$ registered and by DNA, RNA and protein content of fathead minnows (Pimephales promelas). Can. J. Fish. Aquat. Sci., 50: 2245-2253.

Reish, D.L. and P.S. Oshida, 1986. Manual of methods in aquatic environment research. 1st Edn., Food and Agriculture Organization of the United Nations, Rome, ISBN-10: 9251025177 pp: 62.

Samuel, O.B., O.Q. Suleiman and W.O. Odiete, 2008. Synergistic evaluation of oil-dispersant and oildetergent mixtures using African Catfish, Clarias gariepinus fry. J. Fish. Aquatic Sci., 3: 280-290.

Sedman, R.M., J. Beaumont, T.A. McDonald, S. Reynolds and G. Krowwech et al., 2006. Review of the evidence regarding the carcinogenicity of hexavalent chromium in drinking water. J. Environ. Sci. Health, 24: 155-182. PMID: 16690539

Silva, E., N. Rajapakse and A. Kortenkamp, 2002. Something from "nothing"-eight weak estrogenic chemicals combined at concentrations below NOEC's produce significant mixture effects. Environ. Sci. Technol., 36: 1751-1756.

Stenersen, J., 2004. Chemical Pesticides: Mode of Action and Toxicology. 1st Edn., Crc Press, Boca Raton, ISBN-10: 0748409106 pp: 276.

Thorp, V.J. and P.S. Lake, 1974. Toxicity bioassays of cadmium on selected freshwater invertebrates and the interaction of cadmium and zinc on the freshwater shrimp, Paratya tasmaniensis Riek. Aust. J. Mar. Freshwater Res., 25: 97-104. DOI: 10.1071/MF9740097

Wang, W.N., A.L. Wang, L. Chen, Y. Liu and R.Y. Sun, 2002. Effects of $\mathrm{pH}$ on survival, phosphorus concentration, adenylate energy charge and $\mathrm{Na}(+)-$ $\mathrm{K}(+)$ ATPase activities of Penaeus chinensis Osbeck juveniles. Aquatic Toxicol., 60: 75-83. DOI: 10.1016/S0166-445X(01)00271-5

WHO, 2004. Guidelines for Drinking-Water Quality: Recommendations. 3rd Edn., World Health Organization, Geneva, ISBN-10: 9241546387, pp: 515. 